Bogdan Ferdek ${ }^{1}$

Papieski Wydział Teologiczny we Wrocławiu

\title{
Aurora Jakuba Böhme w świetle czterech zasad reformacji
}

Obchody 500-lecia reformacji dały impuls do przypomnienia luterańskiego mistyka z Görlitz k. Zgorzelca Jakoba Böhmego. Urodził się on 29 lat po śmierci ks. dr. Marcina Lutra - w 1575 r. i 58 lat po opublikowaniu przez Lutra 95 tez o odpustach. W najbardziej znanym dziele Böhmego - Aurora można usłyszeć echo pierwszej tezy Lutra: „Gdy Pan i Mistrz nasz Jezus Chrystus powiada: Pokutujcie, to chce, aby całe życie wiernych było nieustanną pokutą" ". Böhme daje wskazówki, jak można osiągnąć nieustannie trwającą pokutę ${ }^{3}$ lub jak uprawiać codzienną pokutę ${ }^{4}$. Skoro w Aurorze można usłyszeć echo pierwszej tezy Lutra, zasadnym jest problem, czy można w niej również usłyszeć echo czterech podstawowych zasad reformacji? Tymi czterema zasadami reformacji są: sama taska, sam Chrystus, sama wiara, samo Pismo ${ }^{5}$ (sola gratia, solus Christus, sola fide, sola Scriptura).

Jak zauważa Walerian Słomka: „Myśl Böhmego oddziałała silnie, zwłaszcza w Niemczech, Holandii i Anglii; pod jego wpływem tworzyli m.in. Angelus Silesius [...] F.W.J. Schelling, G.W.F. Hegel, N.A. Bierdiajew; budziła też zaintereso-

\footnotetext{
${ }^{1}$ Ksiądz Bogdan Ferdek, urodzony 22 czerwca 1956 roku w Ozimku. Wykładowca teologii dogmatycznej na Papieskim Wydziale Teologicznym we Wrocławiu. Członek: Komitetu Nauk Teologicznych Polskiej Akademii Nauk, Towarzystwa Teologów Dogmatyków, Polskiego Towarzystwa Mariologicznego, Sekcji Polskiej Towarzystwa Bonhoefferowskiego oraz konsultor Komisji Nauki Wiary Episkopatu Polski. Autor następujących publikacji: Zukunft als theologisches Problem (2000), Teologiczna futurologia (2001), Eschatologia Taboru (2005), Nasza Siostra - Córa i Matka Pana (2007). Współorganizator konferencji chrystologicznych we współpracy z Wydziałem Teologicznym Uniwersytetu Adama Mickiewicza w Poznaniu oraz konferencji filozoficzno-teologicznych we współpracy z Instytutem Filozofii Uniwersytetu Wrocławskiego.

2 M. Luter, 95 tez, Bielsko-Biała 2014, s. 79.

3 J. Böhme, Aurora, Zgorzelec 1998, s. 139.

4 Tamże, s. 140.

5 Zob. M. Uglorz, Marcin Luter Ojciec Reformacji, Bielsko-Biała 1995, s. 125-144.
} 


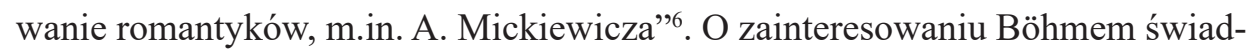
czy obfita literatura ${ }^{7}$. Wśród tych publikacji na uwagę zasługują prace Gerharda Wehra $^{8}$. Z polskich badaczy specjalistą od Böhmego jest wrocławski profesor Józef Kosian9. Wspólnym mianownikiem publikacji poświęconych Böhmemu jest ukazywanie i komentowanie jego mistyki. Mistyka Böhmego budziła sprzeciw ortodoksyjnego luteranizmu. Ewangelicki proboszcz kościoła Piotra i Pawła w Görlitz Gregorius Richter dopatrzył się w Aurorze herezji i zagroził Böhmemu banicją. A zatem uzasadnionym zadaniem jest spojrzenie na najbardziej znane pismo Böhmego Aurora w świetle czterech zasad reformacji. Mistykę Böhmego z teologią Lutra porównał już szczegółowo Heinrich Bornkamm ${ }^{10}$. Niniejszy artykuł stawia sobie skromniejsze zadanie - spojrzenie na Aurorę w świetle czterech zasad reformacji.

\section{Sama laska}

Słowo łaska ma dzisiaj pejoratywne znaczenie. Tymczasem w pozdrowieniach Apostoła Pawła znajduje się słowo łaska. W Pierwszym Liście do Tesaloniczan, uważanym za najstarszą księgę Nowego Testamentu, Apostoł pozdrawia adresatów tego listu: „Łaska wam i pokój!”(1, 1). Reformacja była sporem o łaskę. W wyniku tego sporu rozpadło się zachodnie chrześcijaństwo. Biblijną naukę o łasce zaciemniała praktyka odpustów. Odpusty były jakby próbą zapewnienia sobie zbawienia przez samego człowieka. Tymczasem Apostoł Paweł w Liście do Efezjan naucza: „Łaską bowiem jesteście zbawieni przez wiarę. A to pochodzi nie od was, lecz jest darem Boga: nie z uczynków, aby się nikt nie chlubił" (Ef 2, 8-9). To zdanie mogłoby być streszczeniem całego nauczania Lutra. Zbawienie grzesznika z łaski uważa Luter za artykuł, od którego zależy istnienie Kościoła. Łaska bowiem usprawiedliwia grzesznika przed Bogiem. Dzięki łasce grzesz-

${ }^{6}$ W. Słomka, Böhme Jakob, w: Encyklopedia Katolicka II (red. F. Gryglewicz, R. Łukaszyk, Z. Sułowski) Lublin 1985, s. 732-733.

${ }^{7}$ Zob. W. Słomka, dz. cyt., s. 733; por: B. Sill, Böhme, w: Lexikon für Theologie und Kirche II, Freiburg im Breisgau 2006, s. 551; F.v.Ingen, Böhme, w: Marienlexikon (red. R. Bäumer, L. Scheffczyk) ST. Ottilien 1988, s. 520.

${ }^{8}$ Zob. G. Wehr, Jakob Böhme - der Geisteslehrer und Seelenführer, Freiburg 1979; G. Wehr, Jakob Böhme. Ursprung, Wirkung, Textauswahl, Wiesbaden 2010; G. Wehr, Die deutsche Mystik, Köln 2006.

${ }^{9}$ Zob. J. Kosian, Mistyka Śląska. Mistrzowie duchowości śląskiej: Jakub Boehme, Anioł Ślazak, Daniel Czepko, Wrocław 2001. Zob. również: L. Kleszcz, Jacob Böhme - kontekst narodzin mistyki ślaskiej, w: Między transcendencją a immanencją - mistyka ślaska (red. B. Ferdek, L. Miodoński) Wrocław 2015, s. 25-40; L. Miodoński, Motyw przebudzenia duchowego w mistyce ślaskiej, w: Między transcendencją a immanencja - mistyka śląska, dz. cyt., s. 43-60.

${ }_{10}$ Zob. H. Bornkamm, Luther und Jacob Böhme, Bonn 1925. 
nik staje się simul iustus et peccator, czyli usprawiedliwionym i równocześnie grzesznikiem $^{11}$. W człowieku są więc równocześnie łaska i grzech.

Echo nauki Lutra o łasce usprawiedliwiającej grzesznika można odnaleźć u Böhmego. Uważa się on za biednego grzesznika ${ }^{12}$, który jednak dzięki łasce „stoi niczym piękna róża pośród cierni”'13. Grzesznego człowieka może usprawiedliwić tylko sama łaska, ponieważ jego wola jest niewolna. Wyjaśniał to Luter w swoim dziele $O$ niewolnej woli. Luter porównuje wolę człowieka do pociągowego bydlęcia. Gdy siądzie na nim Chrystus, to idzie ono tam, dokąd chce Chrystus. Jeżeli zaś usiądzie na nim diabeł, to idzie tam, gdzie chce diabeł ${ }^{14}$. A zatem nie od woli człowieka zależy to, czy idzie on za Chrystusem, czy za diabłem, lecz to Chrystus lub diabeł decydują o tym, dokąd idzie człowiek. Podobnie jak Luter wypowiada się Böhme. Porównuje on człowieka do leniwego osła, o którego walczą między sobą stary Adam - posłuszny szatanowi, i nowy Adam - posłuszny Chrystusowi. Zarówno stary Adam, jak i ten nowy Adam okładają batem leniwego osła, aby czynił to, czego nie chce ${ }^{15}$. Jeżeli leniwy osioł idzie za nowym Adamem, to działa i pragnie w nim Bóg, który mieszka w opanowanej woli człowieka. Wola człowieka jest wtedy ,prześwietlona boskim światłem, jak ogień żarem przenika żelazo, stąd traci ono ciemność"16. Dzięki zamieszkaniu Boga w niewolnej woli człowieka wstępuje ona do nieba. Jeżeli zaś leniwy osioł idzie za starym Adamem, to pełni wolę szatana, co objawia się w złości, kłamstwie, pysze, skąpstwie, zazdrości i gniewie. Dzięki zamieszkaniu woli szatana w niewolnej woli człowieka, człowiek wstępuje do piekła ${ }^{17}$. Człowiek nie może więc zbawić się sam, bo jego wola jest niewolna i dlatego do zbawienia potrzebuje łaski. W Aurorze Böhmego zawarta jest zatem reformacyjna zasada sama łaska i implikująca ją antropologia o niewolnej woli człowieka. Tą zasadę i implikującą ją antropologię odnosił Böhme również do Maryi, Matki Jezusa. Była Ona, tak jak wszystkie inne kobiety, człowiekiem, a tym samym nie była wolna od grzechu. Dopiero kiedy przepełniony łaską Bóg wybrał ją na matkę swego Syna, została ona uznana za wolną od grzechu. Maryja jest przykładem na to, co Bóg potrafi uczynić swoją łaską z człowiekiem. Po wieki nie zostanie zapomniane, że Bóg stał się w niej człowiekiem ${ }^{18}$.

W przeciwieństwie do Böhmego, Adam Mickiewicz w swoim wykładzie O Jakobie Böhme uczynił w antropologii Böhmego o niewolnej woli wyjątek,

\footnotetext{
${ }^{11}$ Zob. M. Uglorz, dz. cyt., s. 137-142.

12 J. Böhme, Aurora, dz. cyt., s. 49.

13 Tamże, s. 149.

${ }_{14}$ M. Luter, O niewolnej woli, Świętochłowice 2002, s. 108.

15 J. Böhme, Aurora, dz. cyt., s. 130.

16 Tamże, s. 148.

17 Tamże.

18 E. von Ingen, dz. cyt., s. 518.
} 
którym jest Maryja, Matka Jezusa. Według Mickiewicza, „Bóg stworzył kobietę nową, kobietę rajską, jedyną kobietę prawdziwą przeznaczoną na matkę Istoty Świetlanej, Słowa Bożego. Jej wyjątkowe stworzenie stawiało ją cieleśnie ponad zamachami Złego; ale jako duch musiała ona czynić wysiłki, by się utrzymać na wyżynie swego przeznaczenia; mogła była upaść, ale pozostała wierną swemu prawu, i stała się tym sposobem istotą wyjątkową, naczyniem Słowa Bożego"19. Maryja jest więc, tak jak wszystkie inne kobiety, człowiekiem, ale wolnym od grzechu i mającym wolną, a nie niewolną wolę.

\section{Sam Chrystus}

Lutra jako teologa interesowało przede wszystkim wydarzenie Jezusa Chrystusa, zwłaszcza wszystkie aspekty Jego śmierci, która stała się źródłem łaski usprawiedliwiającej grzeszników. Osobą Chrystusa, łączącą w sobie boską i ludzką naturę, Luter interesował się tylko w związku z teologią krzyża. Ofiara krzyżowa Jezusa jest lekarstwem na grzech i śmierć. Leczy ona z tych największych chorób, jakie dotknęły człowieka ${ }^{20}$.

Z kolei Böhme interesował się bardziej osobą Chrystusa. On jako Syn Boży „Zawsze przez wieczność jest rodzony a nie czyniony z wszystkich sił swego Ojca"21. Chrystus ,jest drugą osobą za Ojcem, ale nie drugim Bogiem"”22. Jest Kimś innym niż Ojciec, ale ma to samo, co Ojciec - jest wszechmocny jak Ojciec, „widzi, słyszy, smakuje, czuje, wącha i pojmuje wszystko jak Ojciec”23. Syn jest światłością pochodzącą z Ojca - ,jaśnieje w całym Ojcu, tak jak słońce w całym świecie"24. Chrystus jest więc Aurorą. Tą Aurorę dostrzegł w odbłysku słońca na cynowym talerzu w 1600 roku. Nazwanie Chrystusa Aurora jest zgodne z nauczaniem starochrześcijańskich teologów, którzy relację Ojca do Syna przedstawiali za pomocą porównania Chrystusa do promienia światła w odniesieniu do źródła, z którego ono płynie. Już w starochrześcijańskiej poezji Chrystus był nazywany Aurora, co było bardzo odważnym zabiegiem. Aurora była bowiem w mitologii rzymskiej boginią zorzy porannej. W sztuce starożytnego Rzymu najczęściej przedstawiano ją na rydwanie zaprzężonym w dwa konie w szacie koloru szafranowego. Dla chrześcijan Aurorą stał się Chrystus i dlatego w nicejsko-konstantynopolitańskim wyznaniu wiary został On nazwany Światłościa ze świattości. „Przedstawienie Chrystusa jako jutrzenki jest najbardziej śmiałym

\footnotetext{
19 A. Mickiewicz, O Jakobie Böhmem, w: J. Böhme, Aurora, dz. cyt., s. 181.

${ }^{20}$ Zob. M. Uglorz, dz. cyt., s. 130-133.

21 J. Böhme, Aurora, dz. cyt., s. 73.

22 Tamże.

23 Tamże.

${ }^{24}$ Tamże, s. 72.
} 
zabiegiem poetyckim, z jakim można się spotkać w odniesieniu do tego motywu w dotychczasowej poezji chrześcijańskiej. Epicki topos, który od Homera był obecny w literaturze, przeszedł nie tylko do poezji chrześcijańskiej, ale także do tekstu religijnego, modlitewnego, zyskując zupełnie nowe znaczenie, otwierając tym samym drogę dla nowej, chrześcijańskiej interpretacji starego motywu"25.

U Böhmego pojawia się również, bliski Lutrowi, motyw teologii krzyża. Chrystus ponownie zrodził ludzi ze swojego umierania. Przez Jego śmierć życie osiągnęło wieczną wolnośćc6. Dlatego „krzyż Pana naszego Chrystusa zmienia się w delikatne dobrodziejstwo i staje się milszy niż cześć i dobra świata"27.

Böhme postuluje naśladowanie Chrystusa: „Ciało zostanie postawione do naśladowania Pana naszego Chrystusa"28. Pismo Böhmego $O$ życiu ponadzmysłowym przypomina swoją strukturą dzieło Tomasza à Kempisa $O$ naśladowaniu Chrystusa. Obydwa pisma zawierają dialog ucznia z mistrzem. Postulat naśladowania Chrystusa nie pojawia się u Lutra. Bez naśladowania Chrystusa przyniesiona przez Niego łaska będzie łaska tania, a nie łaska droga - jak to określił urodzony w Breslau ewangelicki teolog Dietrich Bonhoeffer, którego najbardziej znanym dziełem jest Naśladowanie. Według Bonhoeffera, taska tania usprawiedliwia grzech, a nie grzesznika, według zasady: Grzesz śmiało, ale śmielej jeszcze wierz ${ }^{29}$. Natomiast łaska droga wzywa do naśladowania Chrystusa ${ }^{30}$.

Według ewangelickiego teologa Manfreda Uglorza, „Wittenberski Reformator pojmował Jezusa Chrystusa, Syna Bożego, funkcjonalnie. W jego teologii rozważania nad osobą Chrystusa Pana pozostają na marginesie reformacyjnego kazania o zbawczym czynie Syna Bożego. Ważne one były dla Lutra o tyle, o ile mógł je zużytkować w swojej teologii krzyża"31. O ile u Lutra przeważała chrystologia funkcjonalna, o tyle u Böhmego - chrystologia esencjalna. Esencją tej chrystologii jest nazwanie Chrystusa Aurora. Z esencjalnej chrystologii Böhme wyprowadził jednak funkcjonalny wniosek, jakim jest postulat naśladowania Chrystusa.

\section{Sama wiara}

Wiarę ujmuje się jako fides qua, czyli akt wierzenia lub zaufania oraz fides quae, czyli to, w co się wierzy lub co się wyznaje. Luter wyakcentował wiarę jako fides qua, czyli zaufanie Chrystusowi. Według Uglorza, „Wiara nie jest poznaniem określonej sumy prawd objawionych przez Boga w Piśmie Świętym

\footnotetext{
25 J. Adamiak, Motyw Aurory w antycznej poezji chrześcijańskiej, Vox Patrum 33(2013) t. 60, s. 91.

26 J. Böhme, Aurora, dz. cyt., s. 120.

27 Tamże, s. 140.

28 J. Böhme, O życiu ponadzmysłowym, w: J. Böhme, Aurora, dz. cyt., s. 140-141.

${ }^{29}$ D. Bonhoeffer, Naśladowanie, Poznań 1997, s. 17.

${ }^{30}$ Tamże, s. 10.

${ }^{31}$ M. Uglorz, dz. cyt., s. 134.
} 
albo na przykład historii Jezusa Chrystusa. Poznanie historii Jezusa Chrystusa to rodzaj pewnego rodzaju stadium przygotowawczego wiary [...] Wiara - to serdeczne zaufanie łaskawemu Bogu i pewność, że Bóg okazuje grzesznikowi swoje ojcowskie serce w Jezusie Chrystusie" ${ }^{32}$.

Böhme wspomina o wierze jako fides qua, gdy np. pisze, że „Chrystus w rzeczy samej mieszka w wierze tych, którzy oddają mu się całkowicie ${ }^{33}$. To całkowite oddanie się Chrystusowi jest właśnie zaufaniem, czyli wiarą rozumianą jako fides qua. Jednak Böhmego bardziej interesuje wiara jako fides quae. W Aurorze stosunkowo dużo miejsca poświęca wyjaśnianiu przedmiotu wiary, np. najważniejszej prawdzie wiary o Trójcy Świętej. Według Böhmego, „Jeśli więc mówi się i pisze się o trzech osobach w boskości, tedy nie wolno ci myśleć, że wynika stąd trzech bogów, gdzie każdy panuje i rządzi podobnie jak ziemscy królowie na ziemi" ${ }^{34}$. Ponieważ wszystko zostało stworzone przez Trójcę Świętą, dlatego wszystko nosi ślady Trójcy Świętej. Böhme pisze więc, że: „Każda rzecz w tym świecie jest stworzona na podobieństwo tej Troistości. Wy zaślepieni Żydzi, Turcy i poganie, otwórzcie oczy waszego umysłu, muszę wam bowiem pokazać w waszym ciele i wszystkich naturalnych rzeczach, w ludziach, zwierzętach, ptakach i robakach, tak jak w drzewie, kamieniu, zielu, listowiu i trawie, podobieństwo tej Świętej Troistości w Bogu" "35. Böhme widzi więc ślady Trójcy Świętej w tym, co zostało przez Nią stworzone, podobnie jak starochrześcijańscy teologowie. Wyjaśniając misterium Trójcy Świętej, odwoływali się oni do naturalnych analogii. Przykładowo: umysł, słowo i tchnienie są czymś jednym, tworzą jeden proces powstawania mowy, a zarazem są różne; Ojciec, Syn i Duch Święty to tak jak: korzeń, krzak i owoc lub słońce, promień i ciepło. W tych porównaniach występuje jedność, w której są różnice. Stosując te porównania do wyjaśniania misterium Trójcy Świętej, trzeba jednak pamiętać, że Trójca jest ponad wszelkim obrazem.

W przeciwieństwie do Lutra, który koncentrował się na fides qua, Böhme skupia się przede wszystkim na fides quae.

\section{Samo Pismo}

Dla Lutra jedynym źródłem wiary oraz norm chrześcijańskiego życia jest Pismo Święte. W sprawach wiary i etyki Biblia jest pewnym i niezawodnym autorytetem, bo nie może się mylić. Przez jej karty przemawia bowiem Bóg ${ }^{36}$.

\footnotetext{
32 Tamże, s. 142.

33 J. Böhme, Aurora, dz. cyt., s. 156.

${ }^{34}$ Tamże, s. 76.

35 Tamże.

${ }^{36}$ Zob. M. Uglorz, dz. cyt., s. 125-127.
} 
Idąc za Lutrem, Böhme niemal na każdej stronie Aurory odwołuje się do tekstów biblijnych. Najczęściej odwołuje się do pierwszych kart Biblii, która w Księdze Rodzaju mówi o upadku człowieka. Ten upadek związany jest z drzewem. Księga Rodzaju nie mówi o jabłku, które w ikonografii przedstawia upadek człowieka. W łacińskim tłumaczeniu Biblii jest mowa o malum. To łacińskie słowo oznacza zarówno jabłko, jak i zło. W interpretacji Böhmego, Adam i Ewa zjedli nie jabłko, ale zło. Tym złem poczęstował ich diabeł. Jak pisze Böhme: „albowiem szatan jest potężnym Panem we wściekłości i tej samej jest wiecznym księciem. Ale człowiek sam rzucił się w tę wściekłość na skutek upadku Adama i Ewy, że przykleja się do niego zło" ${ }^{\text {"37 }}$. To przyklejenie się zła do człowieka inauguruje walkę pomiędzy państwem niebiańskim i państwem piekielnym.

W państwie niebiańskim działa Henoch, który zaleca pokutę. Gdy ludzie pozostają głusi na wezwanie do pokuty, Bóg karze Sodomę i Gomorę. Zniszczenie tych miast ma być przestrogą przed złem, a zachętą do dobra. Ludzie są jednak dotknięci ślepotą i dlatego Bóg daje im przykazania. Gdy i one nie skłaniają ludzi ku dobru, Bóg posyła im proroków, którzy głoszą im „kazania o świetle”. Wreszcie do ludzi przybywa Chrystus - książę światła, który wyszedł z Bożego serca i stał się człowiekiem i w swoim ludzkim ciele walczył w sile boskiej jasności przeciwko państwu piekielnemu ${ }^{38}$.

Z kolei w państwie piekielnym rządzi książę ciemności - Lucyfer. Został on „wypchnięty ze światła”39. Określając Lucyfera jako wypchniętego ze światta, Böhme nawiązuje do starożytnego teologa Orygenesa, który w Satyrze na śmierć Tyrana znajdującej się u proroka Izajasza widział upadek Lucyfera: „Jakże to spadłeś z niebios, Jaśniejący, Synu Jutrzenki? [...] Ty, który mówiłeś w swym sercu: Wstąpię na niebiosa; powyżej gwiazd Bożych postawię mój tron [...] Wstąpię na szczyty obłoków, podobny będę do Najwyższego" (Iz 14, 12-14) ${ }^{40}$. Lucyfer - książę ciemności, w walce z Chrystusem - księciem światła, posługuje się fałszem $^{41}$. Można w tym widzieć nawiązanie do powiedzenia średniowiecznych teologów, że diabet jest małpa Boga. Diabeł nieudolnie naśladuje Boga. Wie, że zło musi udawać dobro, żeby skusiło człowieka. Człowiek nigdy nie wybierze zła, jeżeli nie będzie ono przybrane w pozory dobra. Szatan wykorzystuje więc swoją inteligencję, aby przedstawiać człowiekowi zło w pozorach dobra i dlatego posługuje się fałszem.

Böhme postrzega historię jako walkę pomiędzy państwem niebiańskim i państwem piekielnym. Taką wizję historii uzasadnia samym Pismem. Pomimo, że Aurora zawiera liczne odwołania do Biblii, to jednak sam tytuł najbardziej

\footnotetext{
37 J. Böhme, Aurora, dz. cyt., s. 32.

38 Tamże, s. 34-35.

39 Tamże, 46.

40 Orygenes, O zasadach, Kraków 1996, s. 103-104.

${ }^{41}$ J. Böhme, Aurora, dz. cyt., s. 34-35.
} 
znanego dzieła Böhmego jest wynikiem doświadczenia z cynowym naczyniem. Luter zarzuciłby Böhmemu iluminaryzm, czyli możliwość wewnętrznego, z pominięciem biblijnego Słowa, komunikowania się Ducha Bożego z człowiekiem. Taki iluminaryzm byłby sprzeczny z zasadą samo Pismo. Według Lutra, Bóg komunikuje się z człowiekiem tylko przez Słowo Boże. Luter nawet w samej Biblii znajdował pewne fragmenty będące - jego zdaniem - niezgodne $\mathrm{z}$ duchem Ewangelii. Nazwał je ciemnymi miejscami. Za takie miejsca uznał 6 i 10 rozdział Listu do Hebrajczyków, List św. Jakuba, List św. Judy i Apokalipsę św. Jana. Uważał, że mają one mniejszą wartość od pozostałych ksiąg ${ }^{42}$.

\section{Podsumowanie}

Liczne teksty Aurory wskazują, że Böhme liczył się z czterema zasadami reformacji. Niemniej jednak miał problemy z ewangelickim proboszczem kościoła Piotra i Pawła w Görlitz. Jeden z egzemplarzy Aurory trafił w ręce pastora Gregoriusa Richtera, który dopatrzył się w Aurorze herezji i zagroził Böhmemu banicją, jeżeli ten nie zaprzestanie pisania. Według Richtera, w Aurorze jest tyle samo bluźnierstw, co zdań i dlatego jest ona bardziej śmiercionośną trucizną niż herezja Ariusza ${ }^{43}$.

Pastora Richtera mógł zaniepokoić już sam początek Aurory, w którym Böhme w jednym zdaniu umieszcza filozofię, astrologię i teologię ${ }^{44}$. Przez astrologię rozumie Böhme siłę gwiazd, która jest przyczyną zła i dobra na świecie ${ }^{45}$. W starożytnym świecie gwiazdy uważano za Boskie moce, które decydują o losach ludzi. Planety noszą imiona bóstw. W chwili, kiedy mędrcy ze Wschodu oddali pokłon Jezusowi, nastąpił kres astrologii. Pokłon mędrców oznacza, że losem Dziecka nie będzie rządziła gwiazda, lecz to Dziecię kieruje gwiazdą.

Według Böhmego, filozofia za swój przedmiot obiera Boga, w którym wszystko ma przyczynę. Człowiek nosi w sobie iskrę ze światła Bożego. Tą iskrą ze światła Bożego jest rozum ${ }^{46}$. Tym rozumem człowiek może wnioskować ze skutków o ich przyczynach, także tej ostatecznej przyczynie - Bogu. Doświadczenie związane z grą blasku światła i cienia na naczyniu cynowym zainspirowało Böhmego do refleksji nad obecnością dobra i zła w całej naturze. Szukając ostatecznej przyczyny dobra i zła, Böhme doszedł do wniosku, że ,skoro każ-

${ }^{42}$ Zob. J. Kozyra, Marcin Luter wobec Listu Jakuba, „Śląskie Studia Historyczno-Teologiczne” 2011, t. 44 nr 2, s. 467-468.

43 Judicium Gregorii Richter, w: J. Kosian, Jakub Boehme - wielki nieznany, w: Studia z filozofii współczesnej, (red.) R. Różanowski, Wrocław 1995, s. 12.

${ }^{44}$ J. Böhme, Aurora, dz. cyt., s. 30.

45 Tamże, s. 47.

46 Tamże, s. 49. 
da rzecz wychodzi z Boga, tedy przecież zło także musi pochodzić z Boga" ${ }^{47}$. W Bogu jest podobnie jak w człowieku: „człowiek ma w sobie żółć, truciznę, a nie może żyć bez żółci”48 W Bogu nie ma żółci, bo jest On duchem. Jednak „W Bogu jest także gorzka jakość, ale nie w tym charakterze i w ten sposób jak w człowieku żółć”49. Böhme zrobił jednak zastrzeżenie: „Nie myśl czasem, że $\mathrm{z}$ tego powodu tryska lub istnieje w Bogu zło i dobro" ${ }^{50}$. W swojej refleksji nad dobrem i złem Böhme inspiruje się luterańską zasadą: simul iustus et peccator. Skoro łaska i grzech mogą koegzystować w tym samym podmiocie, to również dobro i zło mogą koegzystować w człowieku, całej naturze i zdaje się, że również w Bogu. Luter nie byłby zadowolony z pomysłu Böhmego. W 1518 roku opublikował tzw. tezy heildelberskie. 19 z tych tez głosi: „Nie ten jest godzien miana teologa, kto niewidzialną istotę Boga ogląda w dziełach i poznaje umysłem". W komentarzu do tej tezy Luter stwierdza, że ci, którzy „poznają z widzialnego świata niewidzialną istotę Boga, którą stanowi: moc, boskość, mądrość, sprawiedliwość, dobroć etc., są głupcami"51. Taką etykietę głupiec otrzymałby Böhme od Lutra, na co wskazują ostre słowa przedstawiciela ortodoksyjnego luteranizmu, którym był pastor Richter.

Böhme był teozofem, czyli teologiem i filozofem w jednej osobie. Jako teo$\log$ czerpał wiedzę z Bożego Objawienia, a jako filozof postrzegał ślady Boga w świecie. Miał przeczucie, że rozum i wiara nie mogą sobie przeczyć, bo ostatecznie mają wspólne źródło w Bogu. Poszukiwał Prawdy w prawdzie. W świetle Prawdy Pisma Świętego patrzył na prawdy, do których dochodzi rozum. Zaś w prawdach, do których dochodzi rozum, szukał śladów Prawdy zawartej w Piśmie Świętym.

\section{Aurora's Jakub Böhme in light of the four principles of the Reformation}

\section{Summary}

Böhm's mysticism aroused the opposition of orthodox Lutheranism. Evangelical parish priest of the Peter and Paul church in Görlitz Gregorius Richter suspect a heresy in Aurora and threatened Böhm with banishment. Numerous Aurora texts indicate that Böhme took into account the four principles of the Reformation. Böhm's Aurora contains the reformational principle the grace itself and the anthropology implied by it, about the non-free will of human being. While in Luther thoughts were dominated by the functional Christology, in the Böhme's - essential Christology. The essence of this Christology is to call Christ Aurora. From the essential Christology, Böhme, however, derived a functional conclusion, which is the postulate of the following Christ. In contrast

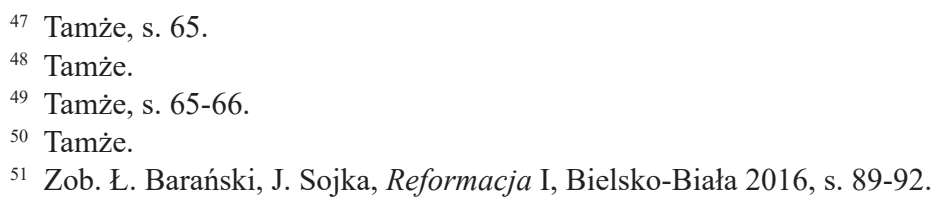


to Luther, who focused on the fides qua, Böhme focuses primarily on fides quae. Although Aurora contains numerous references to the Bible, the very title of Böhme's most famous work is the result of an experience with a tin vessel. Luther would blame Böhme of illumination, that is, the possibility of an internal, omitting the biblical Word, communicating the Spirit of God with human. Böhme was a theosophist, means either theologian and philosopher, in one person. As a theologian, he drew the knowledge from God's revelation, and as a philosopher he perceived the traces of God in the world. He had a premonition that reason and faith can not contradict themselves, because ultimately they have a common source in God.

\section{Keywords}

mysticism, priciples of the Reformation, christology, theosophist

\section{Slowa kluczowe}

mistycyzm, zasady reformacji, chrystologia, teozofia

\section{Bibliografia}

Adamiak J., Motyw Aurory w antycznej poezji chrześcijańskiej, Vox Patrum 33(2013) t. 60, s. 79-92.

Böhme J., Aurora, Zgorzelec 1998.

Bornkamm H., Luther und Jacob Böhme, Bonn 1925.

Bonhoeffer D., Naśladowanie, Poznań 1997.

Ingen, v. F., Böhme, w: Marienlexikon (red. R. Bäumer, L. Scheffczyk), ST. Ottilien 1988, s. 517-520.

Kleszcz L., Jacob Böhme - kontekst narodzin mistyki śląskiej, w: Między transcendencją a immanencja - mistyka ślaska (red. B. Ferdek, L. Miodoński), Wrocław 2015, s. 25-40.

Kosian J., Mistyka Śląska. Mistrzowie duchowości śląskiej: Jakub Boehme, Aniot Ślazak, Daniel Czepko, Wrocław 2001.

Kosian J., Jakub Boehme - wielki nieznany, w: Studia z filozofii współczesnej, (red.) R. Różanowski, Wrocław 1995, 9-25.

Kozyra J., Marcin Luter wobec Listu Jakuba, „Śląskie Studia Historyczno-Teologiczne” 2011, t. 44 nr 2, s. $467-468$.

Luter M., 95 tez, Bielsko-Biała 2014.

Luter M., O niewolnej woli, Świętochłowice 2002.

Miodoński L., Motyw przebudzenia duchowego w mistyce śląskiej, w: Między transcendencja a immanencja - mistyka śląska, w: Między transcendencją a immanencja - mistyka śląska (red. B. Ferdek, L. Miodoński), Wrocław 2015, s. 43-60.

Orygenes, O zasadach, Kraków 1996.

Uglorz M., Marcin Luter Ojciec Reformacji, Bielsko-Biała 1995.

Wehr G., Jakob Böhme - der Geisteslehrer und Seelenführer, Freiburg 1979.

Wehr G., Die deutsche Mystik, Köln 2006.

Wehr G., Jakob Böhme. Ursprung, Wirkung, Textauswahl, Wiesbaden 2010. 